\title{
Sciendo
}

Transport and Telecommunication, 2019, volume 20, no. 1, 40-51

Transport and Telecommunication Institute, Lomonosova 1, Riga, LV-1019, Latvia DOI 10.2478/ttj-2019-0004

\section{MEASUREMENT OF AIRPORT EFFICIENCY. THE CASE OF COLOMBIA}

\author{
Oscar Díaz Olariaga ${ }^{1}$, Luis Pulido Moreno ${ }^{2}$ \\ ${ }^{1}$ Facultad de Ingeniería Civil, Universidad Santo Tomás \\ Carrera 8\#51-11, Bogotá, Colombia \\ OscarDiazOlariaga@gmail.com \\ ${ }^{2}$ Facultad de Ingeniería Industrial, Universidad Santo Tomás \\ Carrera 8 \#51-11, Bogotá, Colombia \\ luis.pulido@usantotomas.edu.co
}

\begin{abstract}
Since the mid-1990s, Colombia's main airports (including those with the highest traffic) have been privatized, transferring governance to private operators. The remaining airports in the network (the smallest ones) continue with public governance. Based on this, the objective of this research article is to know, analyse and even measure the airport efficiency in a context of structural reform and at the same time compare this with the measure in airports with public governance. The methodology used to carry out the study is the Data Envelopment Analysis, and this methodology uses only "technical variables" (that is, only those related to infrastructure). The main results of the research reveal higher efficiency indices in the major (or more important) airports, almost all of them under private governance, although there is also a group of them (usually very small airports) with very low efficiency levels.
\end{abstract}

Keywords: airport, privatization, governance, Data Envelopment Analysis, efficiency, Colombia

\section{Introduction}

The evaluation of airport efficiency has been a research area booming in recent years. These evaluations are important for all players in the industry, airport operators (public and private), regulatory agencies, governments (local, regional and national), and airlines. For this reason, a large number of articles on airport efficiency have been published in the last 15-20 years (lo Storto, 2018; Lai et al., 2012). Regarding the specific techniques adopted in the research, Data Envelopment Analysis (DEA) is one of the most used, started by the work of Gillen and Lall (1997), which was one of the first in the matter.

Many researches, which attempt to measure airport efficiency, cover their analysis at country level (or sometimes encompass continental regions). For instance, there are studies for airports in the United States (Sarkis, 2000; Sarkis and Talluri, 2004), Australia (Abbott and Wu, 2002), Japan (Yoshida and Fujimoto, 2004), the United Kingdom (Parker, 1999), Spain (Martín and Román, 2001), Italy (Malighetti et al., 2007; Barros and Dieke, 2008, 2007), Turkey (Ülkü, 2015; Kocak, 2011), etc. And at continental regional level, i.e., the simultaneous analysis of a set of airports from different countries (and even from different continents and worldwide), we can find the work of Adler and Berechman (2001), Oum et al. (2003, 2004, 2006), Lin and Hong (2006), Pels et al. (2001, 2003), Tsui et al. (2014), Ha et al. (2010), Lam et al. (2009), Yang (2010a, 2010b). It should be mentioned that for the Latin American region there is very little literature, only stand out: a study by Perelman and Serebrisky (2012) where the airport efficiency of several airports in the region was analysed; Barros (2008) examined the technical efficiency of airports in Argentina, and analysed the results in the context of the economic crisis during the 20032007 period; and finally Wanke (2013), and Pacheco and Fernandes (2003) measured the efficiency of airports in Brazil. There is no research (at least published) on the measurement of efficiency in Colombian airports.

So, this research, one of which objectives is to cover this gap in the scientific literature (geographically, both regionally and locally), will take as case study for the measurement of airport efficiency a set of airports in Colombia, the most important ones in the country, and both private and public governance. Air transport in Colombia has been experiencing significant and sustained growth for two decades, as a result of the liberalization of the industry (at the beginning of the 1990s) and which led to the entry of private capital into the airport sector (Díaz Olariaga and Avila, 2015). Since the mid-1990s, and in 
several temporary phases, the country's main airports have been privatized (19 to date, the largest and most important in the network), understanding as such giving in concession (to private operators) only the governance of the airport (never the ownership) (Díaz Olariaga and Carvajal, 2016). Based on this, it is of great interest to know and measure airport efficiency in a context of structural reform (still in progress). Simultaneously, the efficiency of a set of airports will be measured, whose governance (to date) is $100 \%$ public, and this efficiency will be compared with the airports of the first group (with $100 \%$ private governance). And the methodology used to carry out the study is the Data Envelopment Analysis (DEA), which is a methodology used to estimate the relative efficiency of a variable without the need to know in depth the relationship that can occur between the inputs and outputs of a complex system.

\section{Literature Review}

In the last two decades, and worldwide, the academy has researched the impact of different forms of ownership on airport efficiency (lo Storto, 2018; Chen et al., 2017; Lai et al., 2012). And from a methodological point of view, Data Envelopment Analysis (DEA) has become the most popular tool for the analysis and measurement of efficiency.

Some studies find clear evidence of the influence of governance on airport efficiency, others cannot discover any relevant effect, and others show that the effect of governance on airport efficiency depends on many other factors, for example related to the market and the competitive environment, the governance structure (of the airport operator), the type of concession, and even the capacity of the airport to generate economies of scale. Researchers have used different samples, variables, time periods and research methods (lo Storto, 2018). Certain discrepancies between the results obtained in the research are due to differences in the research approach. Contradictory results can be found for the same or similar airport samples in different time frames (Gitto and Mancuso, 2012, Oum et al., 2003, 2006, 2008). The heterogeneities in the samples and the data sets make the comparative studies problematic and can strongly bias the efficiency analysis because the operating environments of the airports are very different (Adler et al., 2013; Marques et al., 2015).

Several researches support the idea that airport efficiency is influenced by the type of governance. In particular, some academics found that privatization increases airport efficiency (Adler and Liebert, 2014; Assaf, 2011, 2010; Gitto and Mancuso, 2012; Malighetti et al., 2007; Marques and Barros, 2011; Marques et al., 2015; Oum et al., 2006; Perelman and Serebrisky, 2012). Adler and Liebert (2014) found that operators of mixed-ownership airports with a public majority are not profitable. Malighetti et al. (2007) studied the efficiency of Italian airports applying a DEA model, they found a positive influence of private governance on airport efficiency. Marques and Barros (2011) investigated the effect that the regulation and governance of a sample of several European airports, their results conclude that airports with public governance are less efficient than airports with private governance. Oum et al. (2006) conducted extensive research on several airports in Asia-Pacific, Europe and North America, and with different types or formulas of governance, their study shows that airports with government majority governance (public) and multilevel governance are less efficient than airports with mostly private governance. A recent work by lo Storto (2018) finds dual results, that is, in the first place his research affirms that the results suggest that the heterogeneity of ownership can exert a substantial influence on airport efficiency; and secondly, it is detected that while airports with PPP structure have greater technical efficiency than the airports operated by public operators, the metafrontier analysis relating to the efficiency of costs and revenues does not provide evidence that the PPP airports work better. In fact, their results show that publicly managed airports achieve comparable or better performance in terms of revenue efficiency.

However, it is possible to find some research whose results showed that airports with public governance were more efficient than with private governance (Curi et al., 2010; Oum et al., 2008; Gutiérrez and Lozano, 2016; Martini et al., 2013). And on the other hand, some works (Lin and Hong, 2006; Gitto and Mancuso, 2012) determined that airport efficiency was not influenced by the airport's type of ownership.

Finally, some academics studied the combined effect of governance and other factors (for example: regulation, market competition, type of concession, etc.) on airport efficiency (Adler and Liebert, 2014; Albalate et al., 2014; Assaf and Gillen, 2012; Bel and Fageda, 2010; Curi et al., 2011; Gillen and Mantin, 2014). Adler and Liebert (2014) found that in relatively uncompetitive conditions public governance airports are less efficient than airports with entirely private governance, while in a competitive environment both operate equally efficiently. Assaf and Gillen (2012) evaluated the overall impact of the governance structure and economic regulation on airport efficiency in a large sample of 
airports in Europe, North America and Australia; the authors found that the type of economic regulation affects efficiency rather than the type of governance. Curi et al. (2011) used bootstrapped DEA to estimate the technical efficiency of a set of Italian airports and their results led them to affirm that the typology of the concession contract could be a source of variation in efficiency. Gillen and Mantin (2014) corroborate these findings by developing a theoretical model to explore the compensation between the type of airport concession and aeronautical revenues; their model shows that privatization may not be recommended unless the potential of the concession's revenues is large enough.

\section{Case Study}

Since the mid-1990s, and in several temporary phases, called generations, the Colombian government gave in concession several airports in the country, a total of 19 to date, including the major and most important ones (and which handle the bulk of the air traffic in the entire network) of the 75 managed by the public aeronautical authority, in order to obtain better administration, modernization and expansion, operation, commercial exploitation and maintenance of the air terminals of greater use (Díaz Olariaga, 2017, 2016a, 2016b). As a result of public policies, both of privatization and of public and private investment in airport infrastructure, together with deregulation policies of the aviation sector where airfares have been fully liberalized since 2012 (Díaz Olariaga and Zea, 2018), in the last two and a half decades passenger transport (total) grew by $863 \%$ (Díaz Olariaga, 2018).

Thus, in Table 1, the information of the privatized airports that are part of this research is presented. To mention that after handing over the airport to the private operator, a significant technological and infrastructure modernization was verified, carried out in very different times according to the size of the airport and the initial investment volume (required by concession contract).

Table 1. Data of 100\% private governance airports. Source: Aerocivil, 2018

\begin{tabular}{|l|c|c|r|}
\hline Airport city & IATA Code & Year of privatization & PAX (2017) \\
\hline Carepa & APO & 2008 & 205362 \\
\hline Medellín & EOH & 2008 & 1070158 \\
\hline Rionegro & MDE & 2008 & 7325740 \\
\hline Barranquilla* & BAQ & 2015 & 2576253 \\
\hline Cartagena & CTG & 2010 & 4590151 \\
\hline Valledupar & VUP & 2010 & 387634 \\
\hline Quibdó & UIB & 2008 & 372618 \\
\hline Montería & MTR & 2008 & 938460 \\
\hline Bogotá & BOG & 2010 & 24694288 \\
\hline Riohacha & RCH & 2010 & 149980 \\
\hline Santa Marta & SMR & 2010 & 1686025 \\
\hline Cúcuta & CUC & 2007 & 875519 \\
\hline Providencia & PVA & 2007 & 71091 \\
\hline San Andrés & ADZ & 2010 & 2328104 \\
\hline Barrancabermeja & EJA & 2010 & 128895 \\
\hline Bucaramanga & BGA & 2008 & 1565482 \\
\hline Corozal & CZU & 2000 & 82675 \\
\hline Cali & CLO & & \\
\hline
\end{tabular}

* The airport of the city of Barranquilla (BAQ) does not participate in the study since it was recently privatized (and there is not enough recent data for the analysis).

On the other hand, Table 2 shows information and details of a group of airports that, since always, have $100 \%$ public governance, and which are also airports that are candidates to be given in concession in the short or medium term. These airports are also part of the efficiency study, which will be compared with the first group (100\% private governance airports). Figure 1 shows the geographical distribution of the airports under study.

Table 2. Data of 100\% public governance airports. Source: Aerocivil, 2018

\begin{tabular}{|l|c|r|}
\hline Airport city & IATA Code & PAX (2017) \\
\hline Pereira $* *$ & PEI & 1541340 \\
\hline Armenia & AXM & 430997 \\
\hline Yopal & EYP & 338963 \\
\hline Neiva & NVA & 298934 \\
\hline Pasto & PSO & 287965 \\
\hline
\end{tabular}

** The airport of the city of Pereira (PEI) was given in concession in mid-2017, but will be handed over to the private operator in 2018 , so for the purposes of this study (and use of statistical data) it can be considered, at the closing of 2017, as of public management. 


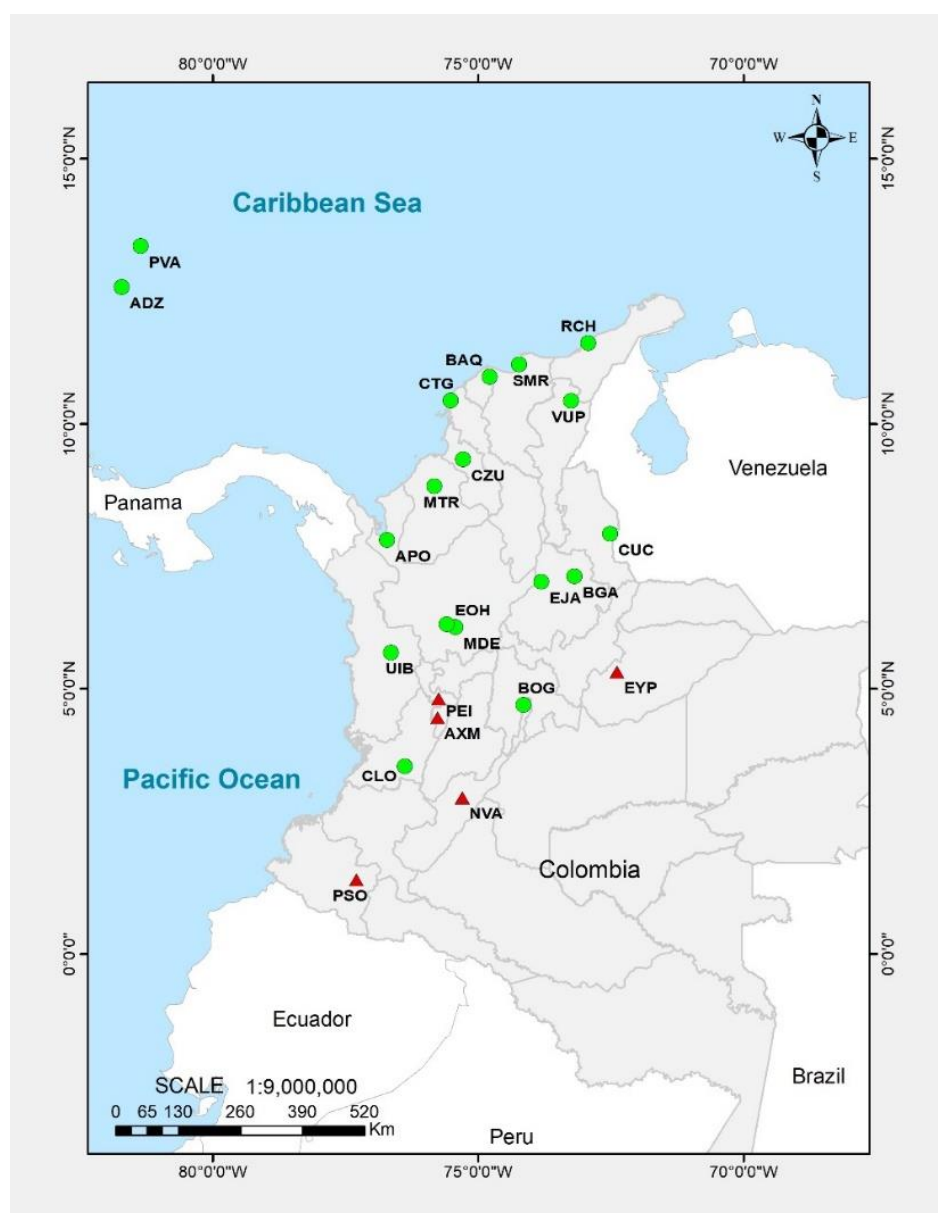

Figure 1. Location of Colombian airports under study; privatized airports (green circles), public airports (red triangles)

\section{Methodology}

\subsection{Basis}

The methodology of Data Envelopment Analysis (which arises from Rhodes' (1978) doctoral thesis and can be considered as an extension of Farrell's (1957) work), used in this research, is considered as a non-parametric solution to estimate the productivity of input factors in a system and the results of its transformation within the process with the use of linear programming (Charnes et al., 1978, 1994). The first DEA model, proposed by Charnes, Cooper and Rhodes (1978), called DEA-CCR, had an input orientation and assumed the existence of constant returns to scale. The second proposed DEA model, known as DEA-BCC (Banker et al., 1984), presents the hypothesis of variable returns to scale. In addition to these two important models, there are other less frequent DEA models in the literature. Thus, at least five other basic DEA models are identified: the additive model (Charnes et al., 1985), the multiplicative model (Charnes et al., 1982), the cone-ratio DEA model (Charnes et al., 1990), the assurance region DEA model (Thompson et al., 1986, 1990) and the super-efficiency model (Andersen and Petersen, 1993).

Thus, in his work Charnes et al., (1978) affirms that in a set of units considered as productive, and that can be compared to each other since their process of transformation of resources is similar (and to define a comparison framework), they name these productive units as DMU (Decision Making Units) and define three types of efficiency to achieve this comparison:

(a) Technical efficiency: the highest productivity unit among units of the same size is chosen as the reference unit.

(b) Scale efficiency: reflects the ability of the DMU to use resources or factors in optimal proportions.

(c) Overall efficiency: the highest productivity unit of those in the study is chosen as the reference unit. 
Efficiency relations are measured with the coefficient obtained between the output results of the system (outputs) and the resources that supplied it at the beginning (inputs), with the following criterion (Charnes et al., 1981):

(a) Input oriented: seeks, given the level of outputs, the maximum proportional reduction in the vector of inputs while remaining in the production possibility frontier. A unit is not efficient if it is possible to decrease any input without altering its output.

(b) Output oriented: seeks, given the level of inputs, the maximum proportional increase of outputs, remaining within the production possibility frontier. A unit is not efficient if it is possible to increase any output without increasing any input and without decreasing any other output.

In general, two types of models are suggested for studies of efficiency calculation:

- CCR model: maximizing a quotient is equivalent to maximizing its numerator if its denominator remains constant, and when a quotient is less than the unit it is because the numerator is less than the denominator.

- BCC model: consists of the resolution of " $n$ " maximization problems corresponding to each of the units whose efficiency is to be evaluated. The objective function chooses the weights that maximize the efficiency of the DMU being studied.

\subsection{Methodological conceptualization}

In this research, "overall efficiency" (or "global efficiency") is understood as the capacity of each analysed airport to make productive use of its input resources, regardless of its size in comparison with other units in the study. To start calculating the overall efficiency of the airports under study, and in accordance with the existing literature, it was decided that each airport would be measured as a DMU and for each one of them the variables that would be taken into account in the analysis as input and output variables were defined, all of them known as "technical variables", that is, the input variables associated with the existing infrastructure (and its characteristics) at the airport, and the output variables associated with aeronautical operations (see Table 3), usually used in similar investigations (see summaries in: lo Storto (2018); Gutierrez and Lozano (2016); Wanke et al. (2016); Ahn and Min (2014)). This research does not use "financial variables" or others of its kind (performance, income segmentation, commercial exploitation, productivity, etc.) because said information, considered confidential, is not provided by local airport operators.

Table 3. Definition of input and output variables of the analysis

\begin{tabular}{|c|c|c|}
\hline DMU & INPUTS & OUTPUTS \\
\hline $\begin{array}{l}\text { Private governance airports (17): } \\
\text { ADZ, SMR, CTG, PVA, MDE, CLO, } \\
\text { APO, MTR, VUP, RCH, BOG, CZU, } \\
\text { UIB, EJA, BGA, EOH, CUC }\end{array}$ & $\begin{array}{l}\text { 1. Number of runways. } \\
\text { 2. Length of the runways. } \\
\text { 3. Number of aircraft parking } \\
\text { positions on the apron. }\end{array}$ & $\begin{array}{l}\text { 1. Operations (takeoffs / landings) } \\
\text { 2. Passengers transported. } \\
\text { 3. Air cargo transported. }\end{array}$ \\
\hline $\begin{array}{c}\text { Public governance airports (5): } \\
\text { AXM, PEI, NVA, PSO, EYP }\end{array}$ & $\begin{array}{l}\text { 4. Built area of the passenger } \\
\text { terminal building. } \\
\text { 5. Area of the apron. }\end{array}$ & \\
\hline
\end{tabular}

The scenarios defined for the analysis were:

- A calculation scenario for private governance airports (17), a scenario for public governance airports (5) and a unified scenario to determine the overall efficiency per year of analysis of the airports under study (22).

- The period is set for the time between the years 2012-2017 (both inclusive) for private governance airports, as well as for public governance airports, where all the information for each DMU is available of the defined input and output variables.

Finally, and following the trend of the existing scientific literature, it was decided to use the DEACCR model, the most used for this type of studies, which offers the possibility of obtaining comparative returns to scale. 


\subsection{Approach of the DEA - CCR Model}

\section{The basic model}

Initially the CCR model was proposed by Charnes et al. (1978). The measure of efficiency they adopted related the weighted sum of inputs with the outputs of each decision unit (DMU) and used linear optimization models to calculate the weights. In any case, the original model was not linear but fractional:

\section{Modifications of the basic model}

This original formulation was modified later (Charnes et al., 1979) so that the weights reach strictly positive values and, thus, avoid that the solution of the program did not consider all the factors and products in the calculation of the efficiency index while avoiding that the denominator of the efficiency quotient was null, and its value did not exist.

Consequently, the model is presented as follows (Tsui et al., 2014):

$\operatorname{Max}_{u, v} h o=\frac{\sum_{r=1}^{s} U_{r} Y_{r o}}{\sum_{i=1}^{m} V_{i} X_{i o}}$

subject to:

$\frac{\sum_{r=1}^{s} U_{r} Y_{r j}}{\sum_{i=1}^{m} V_{i} X_{i j}} \leq 1 \forall j: 1 \ldots n$,

$U_{r}, V_{i} \geq 0 \forall r: 1 . .2 \quad \forall i: 1 \ldots . m$,

where:

$h_{o}$ : Objective function. Measurement of efficiency,

$Y_{r j}: i$-th output of $j$-th DMU,

$X_{i j}: i$-th input of $j$-th DMU,

$V_{i}$ : weights of inputs respectively (program solutions),

$U_{r}$ : weights of outputs respectively (program solutions),

$r: i$-th output,

$j: i$-th input,

$s$ : total numbers outputs,

$m$ : total numbers inputs,

$n$ : total numbers DMU.

\section{Results}

\subsection{Efficiency of private governance airports}

Table 4 presents the result of the calculation of the overall efficiency for the airports analysed, under $100 \%$ private governance, in the period 2012-2017 (both inclusive).

Table 4. Overall efficiency of private governance airports (2012-2017)

\begin{tabular}{|c|c|c|c|c|c|c|c|c|}
\hline Airport & 2012 & 2013 & 2014 & 2015 & 2016 & 2017 & Average & Trend \\
\hline BOG & $92 \%$ & $95 \%$ & $98 \%$ & $100 \%$ & $100 \%$ & $100 \%$ & $97 \%$ & stable \\
\hline UIB & $92 \%$ & $98 \%$ & $96 \%$ & $100 \%$ & $99 \%$ & $95 \%$ & $97 \%$ & decreasing \\
\hline $\mathrm{EOH}$ & $95 \%$ & $95 \%$ & $95 \%$ & $100 \%$ & $92 \%$ & $89 \%$ & $94 \%$ & decreasing \\
\hline CLO & $74 \%$ & $87 \%$ & $90 \%$ & $100 \%$ & $100 \%$ & $97 \%$ & $91 \%$ & stable \\
\hline BGA & $82 \%$ & $89 \%$ & $95 \%$ & $97 \%$ & $88 \%$ & $81 \%$ & $89 \%$ & decreasing \\
\hline CTG & $73 \%$ & $81 \%$ & $80 \%$ & $89 \%$ & $94 \%$ & $100 \%$ & $86 \%$ & growing \\
\hline $\mathrm{APO}$ & $65 \%$ & $73 \%$ & $80 \%$ & $100 \%$ & $87 \%$ & $85 \%$ & $82 \%$ & stable \\
\hline PVA & $71 \%$ & $85 \%$ & $86 \%$ & $88 \%$ & $61 \%$ & $96 \%$ & $81 \%$ & growing \\
\hline SMR & $59 \%$ & $66 \%$ & $66 \%$ & $75 \%$ & $79 \%$ & $87 \%$ & $72 \%$ & growing \\
\hline EJA & $53 \%$ & $61 \%$ & $69 \%$ & $65 \%$ & $55 \%$ & $54 \%$ & $59 \%$ & stable \\
\hline MTR & $41 \%$ & $47 \%$ & $51 \%$ & $56 \%$ & $59 \%$ & $59 \%$ & $52 \%$ & stable \\
\hline CUC & $45 \%$ & $43 \%$ & $45 \%$ & $51 \%$ & $44 \%$ & $38 \%$ & $44 \%$ & decreasing \\
\hline Annual average & $62 \%$ & $68 \%$ & $71 \%$ & $76 \%$ & $73 \%$ & $75 \%$ & $71 \%$ & \\
\hline
\end{tabular}


Table 4 is ordered by the average efficiency obtained in the analysis period, from highest to lowest and also show the trend obtained by the model. The average overall efficiency of this group of airports is $71 \%$ in the period analysed and its lowest value is presented in 2012 with $62 \%$ and its maximum value in the period under analysis is in 2015 with $76 \%$. Figure 2 presents the average overall efficiency, for the period analysed, and for each airport.

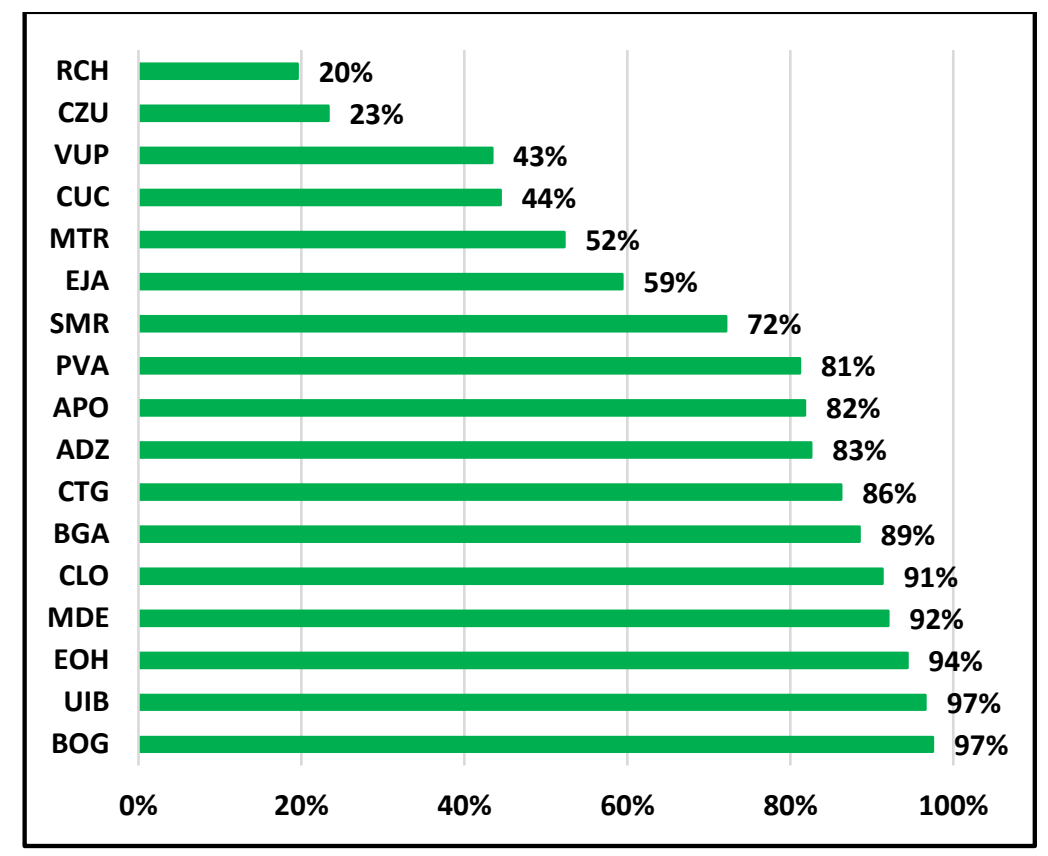

Figure 2. Average overall efficiency, private governance airports (2012-2017)

\subsection{Efficiency of public governance airports}

Table 5 presents the result of the calculation of overall efficiency for airports under $100 \%$ public governance in the period 2012-2017.

Table 5. Overall efficiency of public governance airports (2012-2017)

\begin{tabular}{|c|c|c|c|c|c|c|c|c|}
\hline Airport & $\mathbf{2 0 1 2}$ & $\mathbf{2 0 1 3}$ & $\mathbf{2 0 1 4}$ & $\mathbf{2 0 1 5}$ & $\mathbf{2 0 1 6}$ & $\mathbf{2 0 1 7}$ & Average & Trend \\
\hline EYP & $99 \%$ & $100 \%$ & $100 \%$ & $92 \%$ & $84 \%$ & $73 \%$ & $91 \%$ & decreasing \\
\hline AXM & $66 \%$ & $77 \%$ & $81 \%$ & $94 \%$ & $96 \%$ & $100 \%$ & $86 \%$ & growing \\
\hline PSO & $72 \%$ & $73 \%$ & $77 \%$ & $80 \%$ & $77 \%$ & $73 \%$ & $75 \%$ & decreasing \\
\hline PEI & $63 \%$ & $70 \%$ & $72 \%$ & $72 \%$ & $78 \%$ & $80 \%$ & $73 \%$ & growing \\
\hline NVA & $50 \%$ & $54 \%$ & $48 \%$ & $52 \%$ & $51 \%$ & $53 \%$ & $51 \%$ & growing \\
\hline Annual average & $\mathbf{7 0 \%}$ & $\mathbf{7 5 \%}$ & $\mathbf{7 6 \%}$ & $\mathbf{7 8 \%}$ & $\mathbf{7 7 \%}$ & $\mathbf{7 6 \%}$ & $\mathbf{7 5 \%}$ & \\
\hline
\end{tabular}

Table 5 is arranged by the average efficiency obtained in the analysis period from highest to lowest and includes the trend of the results. The average overall efficiency of this group of airports is $75 \%$ in the period analysed, its lowest value is in 2012 with $70 \%$ and its maximum value in the analysis period is in 2015 with $78 \%$. Figure 3 presents the results of the average overall efficiency of the six years of the period under analysis (2012-2017) for each public governance airport.

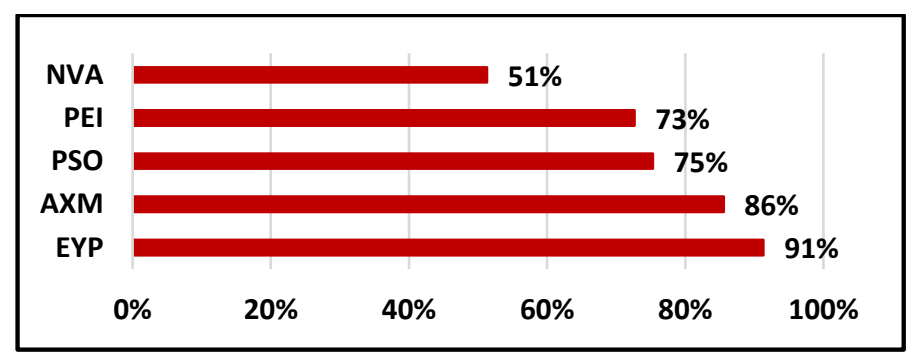

Figure 3. Average overall efficiency, public governance airports (2012-2017) 


\subsection{Comparative analysis}

Figure 4 presents the results of the average overall efficiency of all airports analysed, both with public and private governance.

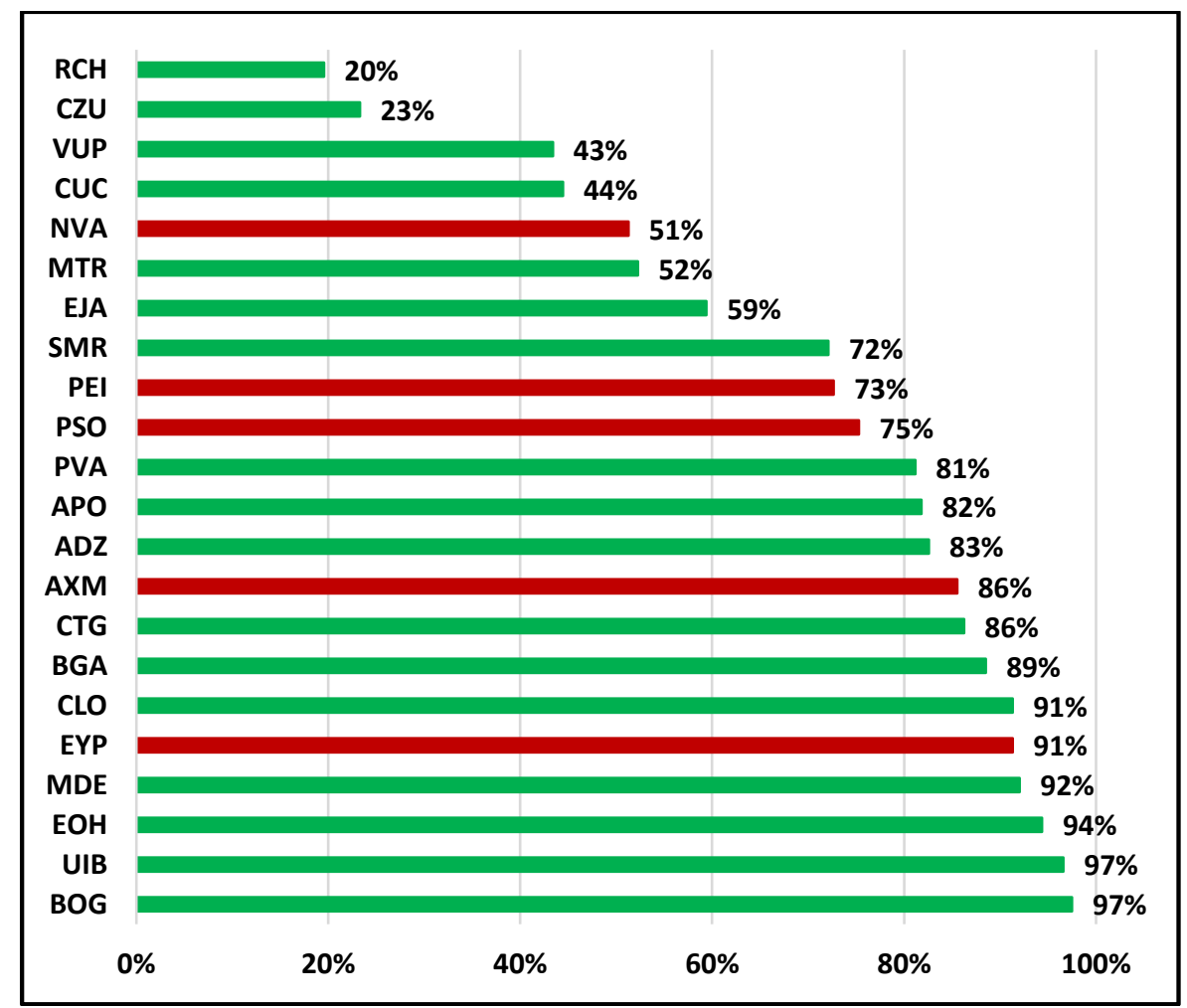

Figure 4. Average overall efficiency, by airport (with public and private governance), for the period analysed (2012-2017)

\section{Discussion and Conclusions}

In this article measures airport efficiency in a context of liberalized air transport market (Diaz Olariaga and Zea, 2018), of considerable level of global investment in airport infrastructure, public and private, with high growth maintained in the last two decades, and which is expected to maintain its current rate of development, at least in the short term. Therefore, in this research the efficiency of a set of airports of the Colombian network has been measured, divided into two groups, a group (of 17) with $100 \%$ private governance, and another group (of 5) with $100 \%$ public governance. The analysis period covers the last six years (2012-2017). Emphasizing that the adopted methodology (DEA) has used for the calculation only the so-called "technical variables", that is, those associated / related to the characteristics of infrastructure (and capacity) of the airports and the aeronautical activity (air traffic). The results obtained lead to the following conclusions:

a) Privatized airports (with $100 \%$ private governance) have high levels of efficiency but only the large airports (with greater air traffic), except for the (small) airport of Quibdó-UIB. Small privatized airports (that is, very low air traffic) have very low efficiency levels (except UIB mentioned above). Same situation with public governance airports.

b) The average efficiency of the group of airports with private governance is not very high in the years of the period analysed (consequence of a large subgroup of airports with very low efficiencies). Although it should be noted that this average has been growing in the period analysed.

c) Many of the privatized airports analysed show significant fluctuations (growth / decrease) of the efficiency levels in the period analysed. Likewise, a growth of the efficiency indices was verified in most of the airports in the analysed period (except in 3 or 4 cases). 
d) For the year 2017 (last year of the analysis period) only 4 privatized airports, of the 17 analysed, have a maximum efficiency level (100\%). In previous years some airports reached the maximum efficiency level $(100 \%)$ but failed to maintain it.

e) The group of airports with $100 \%$ public governance is small (only 5) but they are medium / small airports (and medium or low air traffic) and they play a very important role in the Colombian domestic network due to their geographical location (and the cities they serve), and they are also candidate airports to be given in concession in the short and medium term (following the concessions policy of the Colombian government, in progress since the mid1990s). The average efficiency index for the group is not very high but acceptable (75\% for the entire period analysed).

f) The efficiency indices of public governance airports show fluctuations (growth / decrease) during the development of the analysed period, and except for a couple of cases (EYP and AXM), none reaches the maximum efficiency level in all the years of the period analysed. For the year 2017, except for one airport (AXM), the rest of them show low or very low efficiency levels.

g) In terms of private governance vs. public governance, not much can be conjectured since the largest airports in the country, whatever the nature of their governance, have high efficiency indices, and small airports the same trend but the other way around. Any apparent difference between these two groups of airports (large and small) in terms of efficiency could be due more to their relative size rather than their ownership or governance structure.

Ultimately, this study (the first of its kind in Colombia) is a great first approach to the analysis and evaluation of local airport efficiency, and especially when comparing the governance thereof, in the case of Colombia $100 \%$ public and/or $100 \%$ private (there are no other formulas). It is also important to advance in the coverage and scope of research incorporating new variables, in addition to techniques, such as financial, exploitation, performance, variables of regulatory origin, variables of the competition market, contractual variables (related to concession contracts), etc. This would allow us to know and evaluate much better the performance of the efficiency, determine more accurately if in reality privatization in Colombia improves airport efficiency, and it could even generate standards to be used by all airports in the network and thus be able to perform a rigorous comparative analysis between all the airports in the system.

It would be of great interest if the Colombian public regulatory authority developed, on the one hand, standards to be able to measure, evaluate and accurately compare the efficiency levels of the airports of the network, whatever their governance. And on the other hand, design and implement a (formal) set of inspection procedures to carry out the monitoring and evaluation of all airports. This would facilitate such synergy that would allow less efficient airports to improve their indicators but knowing exactly which ones, where and how to carry out improvement processes. And finally, with the existence of these standards it could be feasible to implement (economic) incentives to the most efficient airports and/or to penalize the least efficient ones if they do not improve their efficiency levels over time.

\section{References}

1. Abbott, M., Wu, S. (2002) Total factor productivity and efficiency of Australian airports. The Australian Economic Review, 35, 244-260.

2. Adler, N., Liebert, V. (2014) Joint impact of competition, ownership form and economic regulation on airport performance and pricing. Transportation Research Part A, 64, 92-109.

3. Adler, N., Liebert, V., Yazhemsky, E. (2013) Benchmarking airports from a managerial perspective. Omega, 41(2), 442-458.

4. Adler, N., Berechman, J. (2001) Measuring airport quality from the airlines' viewpoint: an application of data envelopment analysis. Transport Policy, 8, 171-181.

5. Aerocivil (2018) Estadísticas de Transporte Aéreo. - www.aerocivil.gov.co

6. Ahn, Y-H., Min, H. (2014) Evaluating the multi-period operating efficiency of international airports using data envelopment analysis and the Malmquist productivity index. Journal of Air Transport Management, 39, 12-22.

7. Albalate, D., Bel, G., Fageda, X. (2014) Beyond pure public and pure private management models: partial privatization in the European airport industry. International Public Management Journal, 17(3), 308-327. 
8. Andersen, P., Petersen, N. (1993) A Procedure for Ranking Efficient Units in Data Envelopment Analysis. Management Science, 39(10), 1261-1264.

9. Assaf, A., Gillen, D. (2012) Measuring the joint impact of governance form and economic regulation on airport efficiency. European Journal of Operational Research, 220(1), 187-198.

10. Assaf, A. (2011) Bootstrapped Malmquist indices of Australian airports. The Service Industries Journal, 31(5), 829-846.

11. Assaf, A. (2010) The cost efficiency of Australian airports post privatization: a Bayesian methodology. Tourism Management, 31(2), 267-273.

12. Banker, R., Charnes, A., Cooper, W. (1984) Some Models for Estimating Technical and Scale Inefficiencies in Data Envelopment Analysis. Management Science, 30(9), 1078-1092.

13. Barros, C. (2008) Airports in Argentina: technical efficiency in the context of an economic crisis. Journal of Air Transport Management, 14(6), 315-319.

14. Barros, C., Dieke, P. (2008) Measuring the economic efficiency of airports: a Simar-Wilson methodology analysis. Transportation Research Part E, 44, 1039-1051.

15. Barros, C., Dieke, P. (2007) Performance evaluation of Italian airports: a data envelopment analysis. Journal of Air Transport Management, 13, 184-191.

16. Bel, G., Fageda, X. (2010) Privatization, regulation and airport pricing: an empirical analysis for Europe. Journal of Regulatory Economics, 37(2), 142-161.

17. Charnes, A., Cooper, W., Lewin, A., Seiford, L. (1994) Data Envelopment Analysis: Theory, Methodology and Applications. New York: Kluwer Academic Publishers.

18. Charnes, A., Cooper, W., Huang, M., Sun, D. (1990) Polyhedral Cone-Ratio DEA Models with an Illustrative Application to Large Commercial Banks. Econometrics, 46, 73-91.

19. Charnes, A., Cooper, W., Golany, B., Seiford, L., Stutz, J. (1985) Foundations of data envelopment analysis for Pareto-Koopmans efficient empirical production functions. Journal of Econometrics, 30, 91-107.

20. Charnes, A., Cooper, W., Seiford, L., Stutz, J. (1982) Multiplicative Model for Efficiency Analysis. Socio-Economic Planning Sciences, 16, 223-235.

21. Charnes, A., Cooper, W., Rhodes, E. (1981) Evaluating program and managerial efficiency: An application of data envelopment analysis to program follow through. Management Science, 27, 6, 668-697.

22. Charnes, A., Cooper, W., Rhodes, E. (1979) Short communication: measuring the efficiency of decision making units. European Journal of Operational Research, 3(4), 339.

23. Charnes, A., Cooper, W., Rhodes, E. (1978) Measuring the efficiency of decision making units. European Journal of Operational Research, 2(6), 429-444.

24. Chen, Y., Lai, P., Piboonrungroj, P. (2017) The relationship between airport performance and privatisation policy: A nonparametric metafrontier approach. Journal of Transport Geography, 62, 229-235.

25. Curi, C., Gitto, S., Mancuso, P. (2011) New evidence on the efficiency of Italian airports: A bootstrapped DEA analysis. Socio-Economic Planning Sciences, 45, 84-93.

26. Curi, C., Gitto, S., Mancuso, P. (2010) The Italian airport industry in transition: a performance analysis. Journal of Air Transport Management, 16, 218-221.

27. Díaz Olariaga, O. (2018) Prognosis de tráfico aéreo en contexto de post-liberalización del transporte aéreo. Caso de Colombia. Working Paper. DOI: 10.13140/RG.2.2.11443.73760

28. Díaz Olariaga, O. (2017) Políticas de privatización de aeropuertos. El caso de Colombia. Documentos y Aportes en Administración Pública y Gestión Estatal, 29, 7-35.

29. Díaz Olariaga, O. (2016a) Análisis del desarrollo reciente del transporte aéreo en Colombia. Revista Transporte y Territorio, 14, 122-143.

30. Díaz Olariaga, O. (2016b) Análisis de la evolución de las políticas públicas y de regulación en la industria aeroportuaria en Colombia. Documentos y Aportes en Administración Pública y Gestión Estatal, 26, 7-42.

31. Díaz Olariaga, O., Zea, J.F. (2018) Influence of the liberalization of the air transport industry on configuration of the traffic in the airport network. Transportation Research Procedia, 33, 43-50.

32. Díaz Olariaga, O., Carvajal, A.F. (2016) Efectos de la liberalización en la geografía del transporte aéreo en Colombia. Cuadernos Geográficos, 55(2), 344-364.

33. Díaz Olariaga, O., Ávila, J. (2015) Evolution of the airport and air transport industry in Colombia and its impact on the economy. Journal of Airline and Airport Management, 5(1), 39-66.

34. Farrell, M. (1957) The measurement of productive efficiency. Journal of the Royal Statistical Society. Series A, 3, 253-290. 
35. Gillen, D., Mantin, B. (2014) The importance of concession revenues in the

36. of the Italian airport industry. Journal of Air Transport Management, 20, 39-42.

37. Gutierrez, E., Lozano, S. (2016) Efficiency assessment and output maximization possibilities of European small and medium sized airports. Research in Transportation Economics privatization of airports. Transportation Research Part E, 68, 164-177.

38. Gillen, D., Lall, A. (1997) Developing measures of airport productivity and performance: an application of data envelopment analysis. Transportation Research Part E, 33(4), 261-273.

39. Gitto, S., Mancuso, P. (2012) Two faces of airport business: a non-parametric analysis, 56, 3-14.

40. Ha, H.K., Yoshida, Y., Zhang, A. (2010) Comparative analysis of efficiency for major Northeast Asia airports. Transportation Journal, 49(4), 9-23.

41. Kocak, H. (2011) Efficiency examination of Turkish airports with DEA approach. International Business Research, 4(2), 204-212.

42. Lai, P., Potter, A., Beynon, M. (2012) The development of benchmarking techniques in airport performance evaluation research. Transportation Journal, 51(3), 305-337.

43. Lam, S.W., Low, J.M.W., Tang, L.T. (2009) Operational efficiency across Asia-Pacific airports. Transportation Research Part E, 45(4), 654-665.

44. Lin, L., Hong C. (2006) Operational performance evaluation of international major airports: an application of data envelopment analysis. Journal of Air Transport Management, 12, 342-351.

45. lo Storto, C. (2018) Ownership structure and the technical, cost, and revenue efficiency of Italian airports. Utilities Policy, 50, 175-193.

46. Malighetti, P., Martini, G., Paleari, S., Redondi, R. (2007) An Empirical Investigation on the Efficiency, Capacity and Ownership of Italian Airports. Rivista di Politica Economica, 157-188.

47. Marques, R.C., Simoes, P., Carvalho, P. (2015) The influence of the operational environment on efficiency of international airports. Journal of Advanced Transportation, 49(4), 511-522.

48. Marques, R.C., Barros, C.P. (2011) Performance of European airports: regulation, ownership and managerial efficiency. Applied Economics Letters, 18(1), 29-37.

49. Martini, G., Manello, A., Scotti, D. (2013) The influence of fleet mix, ownership and LCCs on airports' technical/environmental efficiency. Transportation Research Part E, 50(1), 37-52.

50. Martìn, J., Roman, C. (2001) An application of DEA to measure the efficiency of Spanish airports prior to privatization. Journal of Air Transport Management, 7, 149-157.

51. Oum, T.H., Yan, J., Yu, C. (2008) Ownership forms matter for airport efficiency: a stochastic frontier investigation of worldwide airports. Journal of Urban Economics, 64(2), 422-435.

52. Oum, T.H., Adler, N., Yu, C. (2006) Privatization, corporatization, ownership forms and their effects on the performance of the world's major airports. Journal of Air Transport Management, 12(3), 109121.

53. Oum, T., Yu, C., Fu, X. (2003) A comparative analysis of productivity performance of the world's major airports: summary report of the ATRS global airport benchmarking research report 2002. Journal of Air Transport Management, 9, 285-297.

54. Oum, T., Zhang, A., Zhang, Y. (2004) Alternative forms of economic regulation and their efficiency implications for airports. Journal of Transport Economics and Policy, 38, 217-246.

55. Pacheco, R., Fernandes, E. (2003) Managerial efficiency of Brazilian airports. Transportation Research Part A, 37, 667-680.

56. Parker, D. (1999) The performance of BAA before and after privatization. Journal of Transport Economics and Policy, 33, 133-145.

57. Pels, E., Nijkamp, P., Rietveld, P. (2001) Relative efficiency of European airports. Transport Policy, 8, 183-192.

58. Pels, E., Nijkamp, P., Rietveld, P. (2003) Inefficiencies and scale economies of European airport operations. Transportation Research Part E, 39, 341-361.

59. Perelman, S., Serebrisky, T. (2012) Measuring the technical efficiency of airports in Latin America. Utilities Policy, 22, 1-7.

60. Rhodes, E. (1978) Data envelopment analysis and approaches for measuring the efficiency

61. of decision-making units with an application to program follow-through in U.S. education. Ph.D. dissertation. Carnegie-Mellon University.

62. Sarkis, J., Talluri, S. (2004) Performance based clustering for benchmarking of US airports. Transportation Research Part A, 38, 329-346.

63. Sarkis, J. (2000) An analysis of the operational efficiency of major airports in the United States. Journal of Operations Management, 18, 335-51. 
64. Thompson, R., Langemeier, L., Lee, C., Lee, E., Thrall, R. (1990) The Role of Multiplier Bounds in Efficiency Analysis with Application to Kansas Farming. Econometrics, 46(1), 93-108.

65. Thompson, R., Singleton, E., Thrall, R., Smith, B. (1986) Comparative Site Evaluations for Locating High Energy Physics Lab in Texas. Interfaces, 16(6), 35-49.

66. Tsui, W., Balli, H., Gilbey, A., Gow, H. (2014) Operational efficiency of Asia-Pacific airports. Journal of Air Transport Management, 40, 16-24.

67. Ülkü, T. (2015) A comparative efficiency analysis of Spanish and Turkish airports. Journal of Air Transport Management, 46, 56-68.

68. Wanke, P., Barros, C., Nwaogbe, O. (2016) Assessing productive efficiency in Nigerian airports using Fuzzy-DEA. Transport Policy, 49, 9-19.

69. Wanke, P.F. (2013) Physical infrastructure and flight consolidation efficiency drivers in Brazilian airports: a two-stage network-DEA approach. Journal Air Transport Management, 31, 1-5.

70. Yang, H.H. (2010a) Measuring the efficiency of Asia-Pacific international airports-Parametric and non-parametric evidence. Computers \& Industrial Engineering, 59(4), 697-702.

71. Yang, H.H. (2010b) Efficiency and productivity evidence from international airports in the AsiaPacific region. Journal of the Chinese Institute of Industrial Engineers, 27(2), 157-168.

72. Yoshida, Y., Fujimoto, H. (2004) Japanese-airport benchmarking with the DEA and endogenousweight TFP methods: testing the criticism of overinvestment in Japanese regional airports. Transportation Research Part E, 40, 533-546. 